\title{
Pengembangan Modul Pemrograman Komputer Berbasis Matlab
}

\author{
Syaharuddin ${ }^{1}$, Vera Mandailina ${ }^{2}$ \\ ${ }^{1,2}$ Pendidikan Matematika, Universitas Muhammadiyah Mataram, \\ syaharuddin@ummat.ac.id ${ }^{1}$, vrmandailina@ummat.ac.id ${ }^{2}$
}

\section{INFO ARTIKEL}

Riwayat Artikel:

Diterima: 01-08-2017

Disetujui: 26-09-2017

\section{Kata Kunci:}

Modul

Pemrograman

Matlab

\section{A. LATAR BELAKANG}

Dewasa ini, referensi untuk mata kuliah di perguruan tinggi sangat dibutuhkan. Selain sebagai bahan tambahan pengetahuan bagi mahasiswa juga sebagai titik acuan kefokusan ilmu yang diperoleh mahasiswa. Bahan ajar untuk mata kuliah umum tergolong banyak dan mudah diperoleh. Namun bahan ajar untuk beberapa mata kuliah khusus seperti Pemrograman Komputer, Komputer Lanjutan, Workshop Matematika, dan sebagainya perlu dilakukan pengembangan karena materi ajar yang harus diberikan kepada mahasiswa harus sesuai dengan kebutuhan program studi (lembaga) dan kebutuhan lapangan pekerjaan sebagai tempat aplikasi ilmu yang sudah didapatkan.

Pemrograman Komputer adalah salah satu mata kuliah wajib yang menjadi ciri khas sebuah program studi. Membuat ciri khas itu perlu dikaji lebih dalam lagi karena menjadi hal perbedaan antara lembaga tersebut dengan lembaga yang lain. Namun, referensi untuk mata kuliah ini masih tergolong minim atau terbatas. Jadi, perlu dikembangkan dengan memperhatikan kebutuhan program studi dan lapangan pekerjaan. Nantinya, hasil penelitian ini akan bermanfaat untuk kemajuan kemampuan komputasi, motivasi, dan hasil belajar mahasiswa serta peningkatan kompetensi profesionalisme dosen yang bersangkutan. 
Adapun tujuan penelitian ini untuk menghasilkan produk berupa buku ajar mata kuliah pemrograman komputer berbasis Matlab.

\section{B. MATLAB}

Matlab merupakan singkatan dari Matrix Laboratory yang terdiri dari 5 komponen utama yakni:

1. Toolbar berisi berbagai tool control untuk matlab.

2. Current Folder sebagai tempat folder atau file yang sudah tersimpan dan terhubung dengan matlab.

3. Command Windows sebagai lembar kerja utama di matlab tempat pengguna membangun scribs biasa langsung eksekusi.

4. Workspace sebagai tempat ruang kerja tempat menyimpan berkas atau variabel yang sedang digunakan di Command Windows.

5. Command History sebagai tempat untuk menyimpan semua aktivitas yang ada di Command Windows.

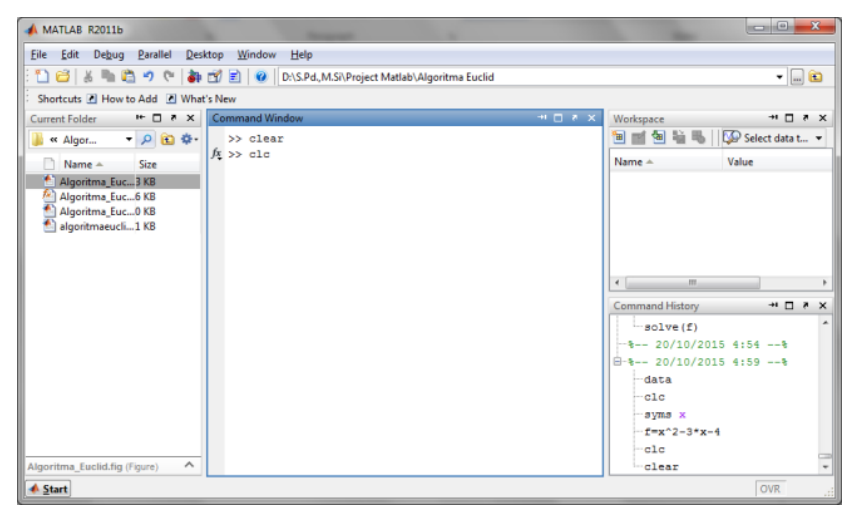

Gambar 1. Tampilan Command Windows

Guide adalah salah satu komponen dari Matlab untuk membuat interface (desain form) proses penyelesaian persoalan matematika yang lebih efisien dan menarik [1]. Tidak seperti 2 bagian lain dari Matlab yakni Command Windows dan m-file (editor) hanya bisa bermain di Command Windows setelah scribs di-running. Di sini, Anda akan membuat form (lembar kerja) untuk masing-masing program aplikasi dengan menggunakan atribut yang sudah disediakan oleh Matlab.

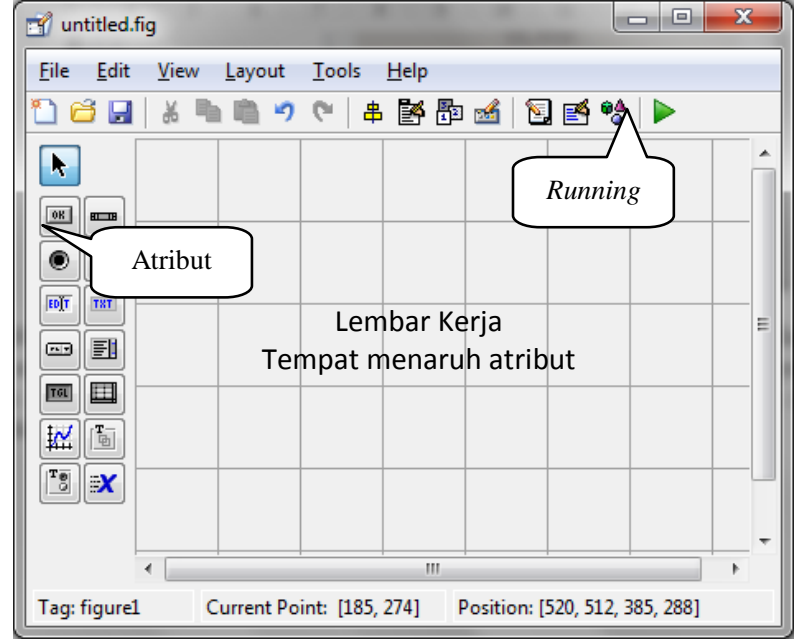

Gambar 2. Guide Kosong

TABEL 1

DAFTAR ATRIUT GUIDE MATLAB [5]

\begin{tabular}{ll}
\hline \multicolumn{1}{c}{ Nama (Hint) } & \multicolumn{1}{c}{ Fungsi } \\
\hline Push Button & Sebagai tombol \\
\hline Slider & Untuk minimumkan tampilan \\
\hline Radio Button & Untuk meletakkan pilihan \\
\hline Check Box & Untuk meletakkan pilihan \\
\hline Edit Text & Sebagai tempat input atau output \\
\hline Static Text & Sebagai label / nama properti \\
\hline Pop-up Menu & Sama dengan Check Box \\
\hline List Box & Sebagai output ketika banyak string \\
\hline ToggleButton & Sama dengan Push Button \\
\hline Table & Output dalam bentuk tabel. \\
\hline Axes & Menggambar grafik/histogram \\
\hline Panel & Mengelompokkan atribut \\
\hline ButtonGroup & Menyatukan atribut \\
\hline ActivexControl & Memunculkan control penting \\
\hline
\end{tabular}

Dalam pembuatan program aplikasi, Anda akan banyak menggunakan atribut: Push Button, Static Text, Edit Text, ListBox, Axes, Table, dan GroupBox. Sedangkan untuk Tollbar yang sering akan digunakan adalah New, Save, Menu Editor, Tool Bar Editor, dan Run.

\section{METODE PENELITIAN}

\section{Model Pengembangan}

Jenis penelitian ini merupakan penelitian pengembangan (Research and Development/R\&D). Penelitian pengembangan adalah metode penelitian yang digunakan untuk menghasilkan produk tertentu, dan menguji keefektivan produk tersebut. Produk yang dihasilkan dalam penelitian pengembangan ini berupa bahan ajar mata kuliah Pemrograman Komputer berbasis Matlab yang meliputi materi kuliah Matematika Dasar, Matematika Diskrit, Kalkulus, dan Statistika. 


\section{Uji Coba Produk}

Uji coba dilakukan setelah melakukan validasi 3 ahli, yakni ahli media pembelajaran, ahli matematika, dan ahli pemrograman. Uji coba terbatas dilakukan pada 5 mahasiswa Prodi Pendidikan Matematika FKIP UMM. Sedangkan uji coba lapangan dilakukan pada 20 mahasiswa Prodi Tadris Matematika FITK IAIN Mataram.

\section{Teknik Analisa Data}

\section{Teknik Analisa Program Aplikasi}

Proses analisis data validitas produk yang dikembangkan dilakukan dengan rumus sebagai berikut [2]:

$$
R=\frac{\sum_{i=1}^{n} V_{i}}{n}
$$

Keterangan:

$R$ : rerata hasil penilaian dari para validator

$V_{i}$ : skor hasil penilaian validator ke-i

$n$ : banyak validator

TABEL 2

INTERVAL NILAI VALIDITAS PRODUK

\begin{tabular}{cl}
\hline Interval Rerata & Tingkat Validitas \\
\hline $\mathrm{R}=5$ & Sangat valid \\
\hline $4 \leq \mathrm{R}<5$ & Valid \\
\hline $3 \leq \mathrm{R}<4$ & Cukup valid \\
\hline $2 \leq \mathrm{R}<3$ & Kurang valid \\
\hline $1 \leq \mathrm{R}<2$ & Tidak valid
\end{tabular}

Teknik Analisis Respon Subjek Uji Coba Produk Data hasil tanggapan (perasaan dan pendapat) mahasiswa melalui angket yang terkumpul, kemudian ditabulasi. Hasil tabulasi tiap respon dicari persentasenya, dengan rumus [4]:

$$
p=\sum \frac{\text { skor per item }}{\text { skormak }} \times 100 \%
$$

TABEL 3

INTERVAL KATEGORI PRODUK

\begin{tabular}{cl}
\hline $\begin{array}{c}\text { Persentase } \\
\text { (\%) }\end{array}$ & \multicolumn{1}{c}{ Kategori } \\
\hline $\mathrm{p} \leq 20$ & Tidak baik (praktis) \\
\hline $20 \leq \mathrm{p}<40$ & Kurang baik (praktis) \\
\hline $40 \leq \mathrm{p}<60$ & Cukup baik (praktis) \\
\hline $60 \leq \mathrm{p}<80$ & Baik (praktis) \\
\hline $\mathrm{p} \geq 80$ & Sangat baik (praktis) \\
\hline
\end{tabular}

\section{HASIL DAN PEMBAHASAN}

\section{Hasil Validasi Ahli}

Dari hasil validasi ahli terhadap bahan ajar diperoleh rata-rata hasil validasi adalah 4,13 yang berarti "valid". Dari hasil validasi ini maka dilanjutkan ke uji coba terbatas dan uji coba lapangan.

\section{Hasil Uji Coba Produk}

Berdasarkan hasil perhitungan maka diperoleh persentasi perasaan dan pendapat subjek pada uji coba produk yakni:

TABEL 4

HASIL ANALISA DATA UJI COBA TERBATAS

\begin{tabular}{lcl}
\hline Indikator & Persentase & \multicolumn{1}{c}{ Keterangan } \\
\hline Perasaan & $68,57 \%$ & Baik \\
\hline Pendapat & $76,25 \%$ & Baik \\
\hline Rata-rata & $73,42 \%$ & Baik / Praktis \\
\hline
\end{tabular}

TABEL 5

HASIL ANALISA DATA UJI COBA LAPANGAN

\begin{tabular}{lcl}
\hline Indikator & Persentase & \multicolumn{1}{c}{ Keterangan } \\
\hline Perasaan & $80,00 \%$ & Baik \\
\hline Pendapat & $77,81 \%$ & Baik \\
\hline Rata-rata & $78,62 \%$ & Baik / Praktis \\
\hline
\end{tabular}

\section{Revisi Produk}

Dari kegiatan validasi bahan ajar terdapat beberapa masukan dari para validator dan responden, baik berkaitan dengan indikator keberhasilan perkuliahan maupun program aplikasi yang disajikan dalam bahan ajar. Adapun bagian-bagian yang direvisi sebagi berikut:

TABEL 6

REVISI PROTOTYPE 1 PADA PROSES VALIDASI

\begin{tabular}{clrlr}
\hline No & \multicolumn{2}{c}{ Sebelum Revisi } & \multicolumn{2}{c}{ Sesudah Revisi } \\
\hline 1 & Program & aplikasi & Program & aplikasi \\
& masih & sedikit & sudah & ditambah \\
& (berjumlah 12) & sebanyak 13 program. \\
\hline 2 & $\begin{array}{l}\text { Pembuatan } \\
\text { project belum ada. }\end{array}$ & Sudah & ditambahkan \\
& dalam Bab 7. \\
\hline
\end{tabular}

TABEL 7

REVISI PROTOTYPE 2 PADA UJI COBA TERBATAS

\begin{tabular}{clcl}
\hline No & \multicolumn{2}{c}{ Sebelum Revisi } & \multicolumn{1}{c}{ Sesudah Revisi } \\
\hline 1 & $\begin{array}{l}\text { Ada beberapa kata/ } \\
\text { kalimat yang salah } \\
\text { ketik }\end{array}$ & Sudah diperbaiki \\
& & \\
\hline 2 & Daftar isi tidak ada & Sudah ada daftar isi \\
\hline 3 & $\begin{array}{l}\text { Penjelasan awal kosa } \\
\text { kata guide masih } \\
\text { kurang }\end{array}$ & Sudah ditambahkan \\
& &
\end{tabular}


TABEL 8

REVISI PROTOTYPE 3 PADA UJI COBA LAPANGAN

\begin{tabular}{cllr}
\hline No & \multicolumn{1}{c}{ Sebelum Revisi } & \multicolumn{1}{c}{ Sesudah Revisi } \\
\hline 1 & Sistem evaluasi & \multicolumn{2}{c}{ Sudah ada dalam bentuk } \\
& perkuliahan belum & tabel kontrol hasil belajar \\
& ada & mahasiswa & \\
\hline 2 & Daftar tugas masih & Sudah & dilakukan \\
& terlihat & pembagian & jumlah \\
& memberatkan & mahasiswa berdasarkan \\
& mahasiswa & bobot program aplikasi. \\
\hline
\end{tabular}

Setelah melakukan revisi sebanyak 3 (tiga) kali, maka diperoleh produk terakhir (Prototype 4) berjumlah 78 halaman yang terdiri dari $7 \mathrm{Bab}$.

Bab 1 Pendahuluan

Bab 2 Command Windows

Bab 3 M-File

Bab 4 Guide: Struktur Urut

Bab 5 Guide: Struktur Percabangan

Bab 6 Guide: Struktur Perulangan

Bab 7 Pengembangan Aplikasi

Adapun indikator masing-masing Bab dijelaskan pada Tabel 9 berikut ini.

TABEL 9

BAB DAN INDIKATOR MODUL

\begin{tabular}{lll}
\hline \multicolumn{1}{c}{ Judul } & \multicolumn{2}{c}{ Indikator } \\
\hline Pendahuluan & - & Komponen Matlab \\
& - & Guide \\
\hline \multirow{3}{*}{ Command } & - & Matematika Diskrit \\
Windows & - & Aljabar Linier \\
& - & Statistika \\
& - & Grafik dan Operasi Fungsi \\
\hline & - & Salkulus \\
M-File & - & Struktur Urut \\
& - & Struktur Percabangan \\
\hline Guide: Struktur & - & Struktur Urut \\
Urut & - & Program Aplikasi \\
\hline Guide: Struktur & - & Struktur Percabangan \\
Percabangan & - & Program Aplikasi \\
\hline Guide: Struktur & - & Struktur Perulangan \\
Perulangan & - & Program Aplikasi \\
\hline Pengembangan & - & MainMenu \\
Aplikasi & - & Aplikasi Project \\
\hline
\end{tabular}

\section{E. SIMPULAN DAN SARAN}

Berdasarkan hasil analisis data dan pembahasan dalam penelitian ini, maka dapat disimpulkan bahwa:

1. Hasil akhir produk yang dikembangkan berupa bahan ajar pada mata kuliah Pemrograman Komputer terdiri dari 7 Bab yakni Bab 1 Pendahuluan, Bab 2 Command
Windows, Bab 3 M-File, Bab 4 Guide: Struktur Urut, Bab 5 Guide: Struktur Percabangan, Bab 6 Guide: Struktur Perulangan, dan Bab 7 Pengembangan Aplikasi

2. Pada tahap validasi ahli diperoleh tingkat kevalidan rata-rata sebesar 4,13 yang berarti "valid". Kemudian pada uji coba terbatas ratarata mahasiswa memberikan respon sebesar $73,42 \%$ yang berarti "baik/praktis". Sedangkan pada uji coba lapangan rata-rata mahasiswa memberikan respon $78,62 \%$ yang berarti "baik/praktis".

Adapun saran untuk penelitian selanjutnya sebagai berikut:

1. Uji coba terbatas dan lapangan dilaksanakan hanya sekali.

2. Bahan ajar ini perlu dikembangkan lagi dengan bidang kajian matematika yang lebih luas agar perbendaharaan mahasiswa dalam system komputasi semakin bertambah.

\section{UCAPAN TERIMA KASIH}

Ucapan terima kasih kepada LEMLIT UM Mataram atas dukugan teknis dan dana yang telah diberikan. Kemudian ucapan terima kasih pula kepada Staf Laboratorium Matematika FKIP UM Mataram selama proses uji coba prdouk.

\section{REFERENSI}

[1] Antony Pranata. (2005). Algoritma dan Pemrograman. Yogyakarta: Graha Ilmu.

[2] Depdiknas. (2011). Pengembangan Bahan Ajar. http://www.jardiknas.org, diakses pada tanggal 25 Pebruari 2011, pukul 20.00 WITA

[3] Parhaini Andriani. (2009). "Pengembangan Akhlak Mulia Dalam Pembelajaran Matematika di SD/MI". Tesis, Universitas Negeri Yogyakarta, Yogyakarta.

[4] Sofan Amri dan Iif Khoiru Ahmadi. (2010). Konstruksi Pengembangan Pembelajaran. Jakarta: Pustaka Pelajar Publisher

[5] Syaharuddin. (2015). Modul Praktikum Matlab Prodi Pendidikan Matematika FKIP UMM 